\title{
Bukti Keilahian Yesus Menurut Injil
}

\author{
Kalis Stevanus \\ Sekolah Tinggi Teologi Tawangmangu, Jawa Tengah \\ kalisstevanus91@gmail.com
}

\begin{abstract}
Jesus' divinity is at the core of the Christian faith. This principle is often doubted by many people and groups. This paper aimed to show strong and convincing shreds of evidence of the divinity of Jesus according to the preaching of the four Gospels; Matthew, Mark, Luke, and John. The writing method used is a biblical analysis of Jesus' capture as God by basing on texts in the four Gospels. The findings showed that there are many texts in the four Gospels that indicated the divinity of Jesus.
\end{abstract}

Keywords: christology; gospel; Jesus; the divinity of Jesus

\begin{abstract}
Abstrak: Keilahian Yesus merupakan inti dari iman Kristen. Prinsip ini seringkali diragukan oleh banyak kalangan. Tulisan ini bertujuan untuk menunjukkan bukti-bukti yang kuat dan meyakinkan tentang keilahian Yesus menurut pemberitaan keempat Injil; Matius, Markus, Lukas dan Yohanes. Metode penulisan yang digunakan adalah analisis biblikal terhadap uangkapan Yesus sebagai Allah dengan mendasarkan pada teks di dalam keempat Injil. Hasil temuan memperlihatkan ada banyak teks dari keempat Injil yang mengindikasikan keilahian Yesus.
\end{abstract}

Kata kunci: Injil; keilahian Yesus; kristologi; Yesus

\section{Pendahuluan}

Adakah ayat di dalam keempat Injil yang menulis bahwa Yesus pernah mengklaim diriNya adalah Allah? Dengan tegas kekristenan mengakui bahwa Yesus disebut sebagai 'manusia sejati' dan sekaligus 'Allah sejati'. Menurut Wijanto, ajaran atau doktrin bahwa Yesus adalah manusia sejati dan Allah sejati ini tidak pernah dapat dijelaskan dengan baik-dan itu berarti juga cukup membingungkan banyak orang dari umat Kristen. Bagi orang non-Kristen, ajaran ini bukan hanya sekadar membingungkan, tetapi juga sering menimbulkan salah mengerti. ${ }^{1}$ Suatu kenyataan dari jaman ke jaman terdapat kritik negatif (baca: serangan) terhadap klaim iman Kristen. Sanggahan-sanggahan yang diajukan untuk melawan klaim iman Kristen memang sangat banyak sekali, sehingga tidak mungkin dibahas satu persatu di dalam tulisan ini. Tulisan ini tidak bermaksud untuk menyelesaikan semua pokok/isu-isu yang menyerang klaim Kekristenan, tetapi di sini secara khusus membahas klaim Yesus sebagai Allah di dalam Injil-Injil saja.

Dalam jaman ini sangat populer untuk percaya bahwa Yesus hidup dan mengajar di masa lampau, namun menolak klaim-Nya sebagai Allah dan hanya mengakui Yesus sebagai manusia biasa. Klaim Kekristenan sering kali dicemooh oleh karena orang Kristen berpegang teguh akan kemanusiaan dan keilahian dari Yesus. Salah satu hal yang sering menjadi batu sandungan dan bahan perdebatan bagi banyak orang adalah perihal ke-Allah-

${ }^{1}$ M.W. Wijanto,”Allah Tritunggal Dalam Injil Yohannes” Gema Teologi Vol.32, No.2, 2018:1 
an Yesus. Kepercayaan Kristen, yang dinyatakan dalam Perjanjian Baru adalah bahwa Yesus dari Nazaret, walaupun satu pribadi, dulu dan sekarang dan selamanya adalah Allah dan manusia. Namun demikian, doktrin Kristen dasar ini semakin banyak dikritik dan bahkan diingkari.

Inilah alasan yang mendasari tulisan ini guna menjawab kritikan dan tuduhan maupun menjawab bagi yang masih meragukan keilahian Yesus. Pengakuan bahwa Yesus itu adalah Allah merupakan doktrin dasar dalam kekristenan yang harus dipegang teguh oleh gereja. Jika dibiarkan, pada akhirnya akan merusak Gereja. Hal ini dikemukakan Robert R. Selvendran: That Jesus is Divine is a profound basic Christian tenet and the airing of dubious views like these, if left unchecked, will eventually undermine the Christian Church. ${ }^{2}$ Gereja tidak boleh mengabaikan berbagai serangan yang meragukan keilahian Yesus. Itu sebabnya pentingnya artikel ini yang bermaksud menghadirkan argumen yang konklusif dari Alkitab untuk menghilangkan keraguan tersebut. Artikel ini diperlukan untuk menjelaskan Keilahian Yesus yang unik khususnya di dalam Injil-Injil.

\section{Metode Penelitian}

Untuk membahas topik ini, pertama penulis melakukan analisis biblikal terhadap klaim Yesus sebagai Allah dengan mendasarkan pada teks-teks di dalam keempat Injil. Teks-teks di dalam Injil-injil tersebut menjadi landasan utama bagi topik bahasan. Penulis juga akan menggunakan referensi dari ayat-ayat lain baik di Perjanjian Baru maupun Perjanjian Lama yang relevan dengan pokok bahasan. Kemudian penulis juga melakukan sebuah kajian literatur dari beberapa sumber pustaka sebagai sumber data sekunder yang kemudian diuraikan dalam sebuah uraian sistematis dan logis sesuai dengan kerangka berpikir yang penulis kemukakan sehingga dapat menjawab persoalan di dalam penelitian ini.

\section{Pembahasan}

Sebelum membahas mengenai klaim Yesus sebagai Allah di dalam Injil-injil, penting sekali untuk mengiakan bahwa Dia adalah manusia yang nyata (benar-benar ada di dalam sejarah). Selanjutnya melihat bukti-bukti bahwa Yesus adalah manusia sejati dan sekaligus Allah sejati. Dalam mempertimbangkan keilahian Yesus, pokok persoalannya "bukanlah" apakah keilahian Yesus mudah dipercaya atau dimengerti, melainkan apakah keilahian Yesus dinyatakan di dalam Alkitab, khususnya di dalam keempat Injil. Satu-satunya tolok ukur yang benar untuk menetapkan apakah Yesus adalah Allah yang menjelma menjadi manusia, atau bukan, tidak lain adalah Alkitab sendiri.

\section{Pengakuan Yesus secara Langsung}

Klaim keilahian Yesus Kristus sebagai Allah merupakan kepercayaan yang berasal langsung dari pengakuan-Nya sendiri. Menurut F.F. Bruce dan W.J. Martin kepercayaan pada keilahian Kristus berasal langsung dari pernyataan tentang Dia di dalam Alkitab, dan klaim kesetaraan Kristus dengan Allah mendasari pengajaran-Nya sejak awal. ${ }^{3}$ Dalam isi dan

\footnotetext{
${ }^{2}$ Robert R. Selvendran, The Unique Divinity of Jesus Christ established from His naming as Saviour (Great Britain: Prontaprint Norwich, 2005), 4

${ }^{3}$ F.F. Bruce \& W.J. Martin, The Deity of Christ (Manchester: North of England Evangelical Trust, 1964), 3
} 
ruang lingkup ajaran-Nya mencakup banyak hal yang baru tentang sifat Allah. Tidak hanya para murid tetapi juga orang-orang Yahudi segera menyadari bahwa Ia menegaskan kesetaraan-Nya dengan Allah (Yoh. 5:18). Pernyataan senada diungkapkan Daniel Doriani bahwa Yesus benar-benar menyadari keilahian-Nya di sepanjang hidup dan pelayananNya: Jesus manifested his awareness of his deity throughout his ministry in frequent and varied actions and teachings that rightly issue from God alone. ${ }^{4}$

\section{Yesus menyebut diri-Nya adalah “Anak Allah” (Luk.22:70)}

Dalam Injil-injil kita dapat menemukan kisah-kisah di mana para penulis Injil memberi informasi kepada para pembacanya bahwa Yesus Kristus adalah Anak Allah. Menurut Suliana Gunawan, pengakuan Yesus sebagai Anak Allah merupakan momentum paling krusial yang tercatat di dalam Injil Sinoptik adalah ketika Petrus memberikan pengakuan kepada Yesus: "Engkau adalah Mesias, Anak Allah yang hidup!" (Mat. 16:16; Mrk. 8:29; Luk. 9:20). Dan pengakuan Petrus tersebut dibenarkan atau diakuinya oleh Yesus sendiri. ${ }^{5}$ Yesus memperkenalkan diri-Nya sebagai Mesias, Anak Allah yang hidup secara terbuka di depan umum. Maksudnya, kerahasiaan mengenai jati diri Yesus dibukakan di depan umum bahwa memang Ia adalah Anak Allah.

Pernyataan Yesus adalah Anak Allah, itu berarti Ia memiliki sifat-sifat yang sama dengan Allah. Seorang anak memiliki sifat yang sama, spesies yang sama, esensi yang sama dengan ayahnya. Scotchmer menyimpulkan seperti yang dikutip Josh McDowell bahwa baik murid-murid maupun musuh-Nya mengerti berdasarkan latar belakang Yahudi mereka bahwa istilah "Anak Allah" tersebut mempunyai arti yang ilahi. ${ }^{6}$ Penulis Injil Markus juga mencatat kisah roh-roh jahat yang menyebut Yesus: "Engkaulah Anak Allah." (Mrk.3:11). Ungkapan atau sebutan ini mengekspresikan suatu kebenaran yang dalam mengenai jati diri Yesus sebenarnya, yang tidak diketahui oleh orang-orang yang sedang berdiri di situ, termasuk para murid-Nya, namun diketahui oleh roh-roh jahat tersebut. Roh-roh jahat itu mengenali Yesus adalah Anak Allah. Itu berarti roh-roh jahat itu mengakui keilahian Yesus.

Injil Markus 14:61-64 menulis: “...Imam Besar itu bertanya kepada-Nya sekali lagi, katanya: "Apakah Engkau Mesias, Anak dari Yang Terpuji?" Jawab Yesus: "Akulah Dia, dan kamu akan melihat Anak Manusia duduk di sebelah kanan Yang Mahakuasa dan datang di tengah-tengah awan-awan di langit." Maka Imam Besar itu mengoyakkan pakaiannya dan berkata: "Untuk apa kita perlu saksi lagi? Kamu sudah mendengar hujat-Nya terhadap Allah. Bagaimana pendapat kamu?" Lalu dengan suara bulat mereka memutuskan, bahwa Dia harus dihukum mati." Tentang pertanyaan Imam Besar, "Apakah Engkau Mesias, Anak dari Yang Mahatinggi?" Jawaban Yesus sangat jelas bahwa Ia menyamakan diri-Nya dengan Allah dengan berkata: "Akulah Dia." Yesus secara terang-terangan

\footnotetext{
${ }^{4}$ Daniel Doriani, “The Deity Of Christ In The Synoptic Gospels" Journal Of The Evangelical Theological Society Vol.37, No.3 (September 1994): 333

${ }^{5}$ Suliana Gunawan, "Rahasia Jati Diri Yesus Dalam Injil Markus: Suatu Tinjauan Terhadap Tesis William Wrede: VERITAS: Jurnal Teologi dan Pelayanan. Vo. 2, No 1 April 2001: 113

${ }^{6}$ Josh McDowell, Apologetika Volume 1 (Malang: Gandum Mas, 2002), 167
} 
menyatakan diri-Nya sebagai Mesias, Anak Manusia dan Anak Allah. Mendengar jawaban Yesus, Imam Besar mengoyakkan pakaiannya.

Yesus dijatuhi hukuman mati, bukan karena berdasarkan perkataan para penuduhnya, melainkan karena pengakuan yang diucapkan-Nya sendiri bahwa Dia telah mengaku sebagai Allah yang sesungguhnya di hadapan para hakim. Dan orang-orang Yahudi pasti mengerti bahwa jawaban Yesus merupakan pengakuan diri-Nya sebagai Allah. Yesus menegaskan hal itu. Imam Besar menyebutnya penghujatan, karena Yesus menjadikan diriNya sama dengan Allah. Jadi, ada dua pilihan yang harus dihadapi: bahwa pernyataan-Nya adalah suatu penghujatan belaka atau bahwa Dia adalah Allah. Dengan demikian, dapat tarik kesimpulan bahwa Yesus sendiri telah menyatakan diri-Nya sebagai Allah dengan cara yang jelas bagi semua orang. Pengakuan ini dianggap sebagai suatu penghujatan oleh para pemuka agama sehingga Dia disalibkan.

Menurut Hank Hanegraaff, sebenarnya mereka tahu bahwa dengan mengatakan bahwa Yesus adalah "Anak Manusia" yang akan datang "di awan-awan di langit" Dia membuat referensi terbuka untuk Anak Manusia dalam nubuat Daniel (Daniel 7: 13-14). Dengan melakukan itu, Dia tidak hanya mengklaim sebagai Penguasa semesta yang sudah ada sebelumnya tetapi juga menubuatkan bahwa Dia akan membenarkan klaim-Nya dengan menghakimi pengadilan yang sekarang sedang mengutuk-Nya. ${ }^{7}$

\section{Yesus mengakui atau menyamakan diri-Nya dengan Allah (Mrk.14:61-64)}

Yesus menyebut Allah itu sebagai Bapa-Nya: "Aku dan Bapa adalah satu” (Yoh.10:30), dan "Barangsiapa melihat Aku telah melihat Bapa" (Yoh.14:9). Ketika Yesus mengakui bahwa "Aku dan Bapa adalah satu", sekali lagi orang-orang Yahudi mengambil batu untuk melempari Yesus. Jawab orang-orang Yahudi itu: "karena Engkau, sekalipun hanya seorang manusia saja, menyamakan diri-Mu dengan Allah" (Yoh.10:33). A.T. Robertson menjelaskan kata "satu" tersebut bersifat netral, bukan maskulin. Artinya, bukan satu orang, tapi satu inti atau satu sifat dasar. Pernyataan yang tegas dan mengena ini adalah puncak dari pengakuan Yesus tentang hubungan di antara Bapa dan diri-Nya sendiri (Anak). ${ }^{8}$ Bagi orang Yahudi ini adalah lambang penghujatan, karena mereka tahu bahwa dengan melakukan hal itu Yesus dengan jelas mengklaim sebagai Allah. ${ }^{9}$

Lebih jauh lagi, di dalam Yoh.5:17-18, "Tetapi Ia berkata kepada mereka: 'BapaKu berkerja sampai sekarang, maka Akupun bekerja juga.' Sebab itu orang-orang Yahudi lebih berusaha lagi untuk membunuh-Nya, bukan saja karena Ia meniadakan hari Sabat, tetapi juga karena Ia mengatakan bahwa Allah adalah Bapa-Nya sendiri dan dengan demikian menyamakan diri-Nya dengan Allah." 10 Jadi kelihatan sekali bahwa tidak ada keraguan sedikit pun di benak orang yang mendengar pernyataan ini bahwa Yesus mengaku di hadapan mereka bahwa Dia adalah Allah.

\section{Yesus mengakui diri-Nya telah ada sebelum Abraham}

Injil Yohanes mencatan ungkapan: "Kata Yesus kepada mereka: 'Aku berkata kepadamu, sesungguhnya sebelum Abraham jadi, Aku telah ada" (Yoh.8:58). Ungkapan "Aku ada"

\footnotetext{
${ }^{7}$ Hank Hanegraaff, "Did Jesus Claim to be God?" Christian Research Journal 28 (4), 2005.

${ }^{8}$ Josh McDowell, Apologetika Volume 1 (Malang: Gandum Mas, 2002), 154

${ }^{9}$ Hanegraaff, "Did Jesus Claim to be God?"

${ }^{10}$ McDowell, Apologetika Volume 1, 155
} 
menurut Perjanjian Lama hanya mengacu pada YHWH yang abadi dan yang ada sejak semula sampai selama-lamanya. "Aku ada" sebagai suatu pernyataan akan keabsolutan keilahian atau ke-Tuhan-an Yesus. Ketika Yesus memproklamirkan bahwa Ia telah ada sebelum Abraham jadi, Ia sedang mengacu para pendengar-Nya kepada kitab Keluaran 3:13-14. Menurut Jonathan A. Draper, bagi Yohanes, Yesus adalah sosok ilahi YHWH yang menampakkan diri kepada Musa di atas batu setelah penglihatan langsung tentang kemuliaan Allah ditolak oleh Musa; Dia adalah Allah 'penuh rahmat dan kebenaran' (Kel $34: 6) .{ }^{11}$

Allah menjawab Musa, "Aku Adalah Aku." Ungkapan, "Aku Adalah Aku" atau "Akulah Aku" menggunakan frasa ego eimi. Menurut Injil Yohanes, Yesus menggunakan istilah $A k u$ adalah lebih dari sembilan belas kali sebagai acuan kepada diri-Nya sendiri. Setiap orang Yahudi dengan nyaring dan jelas akan mendengar tuntutan Yesus atas sifat ketuhanan. Itulah sebabnya orang-orang Yahudi mengambil batu untuk melempari Yesus karena seperti yang mereka katakan,"Engkau, sekalipun hanya seorang manusia saja, menyamakan diri-Mu dengan Allah" (Yoh.10:33).

Pada zaman Tuhan Yesus, sebutan "Akulah Aku" (ego eimi) dalam bahasa Yunani merupakan padanan sebutan untuk YHWH; Nama yang dianggap sakral dan paling dihormati oleh orang Yahudi sehingga mereka tidak berani mengucapkannya. Sebutan ego eimi yang hanya dapat dipakai untuk menyebut Allah, dipakai oleh Yesus. Contoh yang paling jelas adalah, "Kata Yesus kepada mereka: 'Aku berkata kepadamu, sesungguhnya sebelum Abraham jadi, Aku telah ada (ego eimi)." Kesempatan lain, Yesus memakai sebutan itu bagi diri-Nya,"... sebab jikalau kamu tidak percaya, bahwa Akulah Dia (ego eimi), kamu akan mati dalam dosamu" (Yoh.8:24). Dalam Yohanes 8:28, Yesus berkata kepada orang-orang Yahudi, "Maka kata Yesus: Apabila kamu telah meninggikan Anak Manusia, barulah kamu tahu, bahwa Akulah Dia (ego eimi), dan bahwa Aku tidak berbuat apa-apa dari diri-Ku sendiri, tetapi Aku berbicara tentang hal-hal, sebagaimana diajarkan Bapa kepada-Ku." Dan juga Yesus berkata kepada para pasukan yang hendak menangkapNya, Ia bertanya kepada mereka, "Maka Yesus, yang tahu semua yang akan menimpa diriNya, maju ke depan dan berkata kepada mereka: "Siapakah yang kamu cari?" Jawab mereka: "Yesus dari Nazaret." Kata-Nya kepada mereka: "Akulah Dia (ego eimi)."

Yudas yang mengkhianati Dia berdiri juga di situ bersama-sama mereka. Ketika Ia berkata kepada mereka: "Akulah Dia (ego eimi)," mundurlah mereka dan jatuh ke tanah." (Yoh.18:4-6). Karena merasa yakin bahwa Yesus adalah Allah, para penulis Perjanjian Baru dengan jelas menghubungkan Yesus dengan ayat-ayat Perjanjian Lama yang mengacu kepada YHWH. Markus mengutip kitab Yesaya 40:3, "Ada suara yang berseruseru: Persiapkanlah di padang gurun jalan untuk TUHAN (YHWH), luruskanlah di padang belantara jalan raya bagi Allah kita!" Markus menafsirkan bahwa ayat itu digenapi sewaktu Yohanes Pembaptis menyiapkan jalan bagi Yesus.

Tentang Yesaya 40:3, Robert R. Selvendran mengemukakan demikian:

In the fortieth Chapter of Isaiah, there are some announcements which are especially forcible. Take the first; A voice cries: "In the wilderness prepare the way

${ }^{11}$ Jonathan A. Draper, "'If those to whom the W/word of God came were called gods ...'- Logos, wisdom and prophecy, and John 10:22-30” HTS Teologiese Studies/Theological Studies 71 (1), July 2015:1 
of the LORD (Yahweh), make straight in the desert a highway for our God" (v.3). Every gospel refers to this passage and applies it to Jesus as being the person whose way was to be prepared, and John the Baptist as the one whose voice would be heard crying in the wilderness (see Matt. 3:3; Mark 1:3; Luke 3:4; John 1:23). However, the declaration of the passage is that it was the way of Yahweh Himself, our God, which was prepared. ${ }^{12}$

Dengan demikian, tidak diragukan lagi, para pemimpin Yahudi mengetahui dengan siapa Yesus menyamakan diri-Nya. Jadi, tuduhan utama yang dilontarkan oleh para musuh Yesus adalah soal pengakuan-Nya bahwa Dia adalah Allah atau setara dengan Allah.

\section{Yesus Mengatakan Diri-Nya Melebihi Bait Allah}

Ia berkata kepada orang Farisi, "Aku berkata kepadamu: Di sini ada yang melebihi bait Allah" (Mat.12:6). Bait Allah adalah tempat tinggal Allah. Ketika Yesus mengatakan tentang diri-Nya sendiri: yang lebih besar dari Bait Suci ada di sini. Berapa lebihnya? Apa yang bisa lebih besar dari itu? Lihatlah ayat 8, Yesus menegaskan sambil mengacu diriNya,"Anak Manusia adalah Tuhan atas hari Sabat." Secara logis, bagaimana seseorang dapat menjadi Tuhan atas hari Sabat kecuali Allah yang menetapkan hari itu? Ini suatu tuntutan langsung atas sifat ketuhanan-Nya. Jadi, dengan tegas ketika Yesus menyebut diriNya sebagai "Tuhan atas hari Sabat" hal itu merupakan pernyataan bahwa Ia pencipta hari Sabat. Bagi kaum Yahudi, YHWH (baca: Yahweh) adalah Pencipta dan Tuhan atas hari Sabat (band. Kel.3:13,17). Karena itu, dengan mengklaim diri-Nya adalah Tuhan atas hari Sabat, Yesus menegaskan keilahian-Nya.

\section{Yesus Mengklaim Memiliki Hak Dihormati Sama Seperti kepada Allah}

Ia berkata, "Supaya semua orang yang menghormati Anak sama seperti mereka menghormati Bapa. Barangsiapa tidak menghormati Anak, ia juga tidak menghormati Bapa yang mengutus Dia" (Yoh.5:23). Nats ini Yesus memberikan peringatan kepada mereka yang menuduh-Nya sebagai seorang penghujat. Yesus mengatakan bahwa dengan mencaci-maki atau tidak menghormati Diri-Nya sesungguhnya mereka telah mencaci-maki Allah. Di sini jelas Yesus memaklumkan hak-Nya untuk diperlakukan sebagai Allah bahwa melecehkan Yesus sama dengan melecehkan Allah. ${ }^{13}$

\section{Yesus Menerima Penyembahan seperti Allah}

Dalam Matius 5: 20, 22, 26, 28, Yesus mengajar atas nama-Nya sendiri. Bukan seperti para nabi yang mengatakan, "Demikianlah firman Tuhan Allah," tapi Yesus mengatakan, "Sesungguhnya, Aku berkata kepadamu." Di dalam nats-nats lain seperti Matius 8:2, "Maka datanglah seorang yang sakit kusta kepada-Nya, lalu sujud menyembah Dia..." Ada seorang buta sejak lahir setelah disembuhkan, orang itu "sujud menyembah-Nya" (Yoh.9:35-39). Berbeda dengan kesepuluh murid Yesus yang bersaksi kepada Tomas bahwa mereka telah melihat Tuhan (Yoh.20:25). Bahkan Maria Magdalena juga bersaksi bahwa ia telah melihat Tuhan (Yoh.20:18). Tomas menyatakan sikap yang lain: "Sebelum

\footnotetext{
${ }^{12}$ Robert R. Selvendran, The unique Divinity of Jesus Christ established from His naming as Saviour (Great Britain: Prontaprint Norwich, 2005), 8

${ }^{13}$ Kalis Stevanus, Apologetika: Benarkah Yesus Itu Tuhan? (Yogyakarta: Andi, 2016), 212
} 
aku melihat bekas paku pada tangan-Nya dan sebelum aku mencucukkan jariku ke dalam bekas paku itu dan mencucukkan tanganku ke dalam lambung-Nya, sekali-kali aku tidak akan percaya" (Yoh.20:25).

Tomas mengajukan tuntutan bukti sebelum memercayai sesuatu. Sebaliknya, Yesus menyatakan bahwa orang yang percaya akan Dia sebagai Tuhan yang bangkit, sekalipun belum melihat-Nya, adalah orang yang berbahagia. Ketika menghadapi ketidakpercayaan atau keraguan Tomas terhadap kebangkitan-Nya, Ia menyuruh Tomas mencucukkan jarinya ke telapak tangan-Nya bekas paku itu dan mencucukkan tangannya ke dalam lambungNya. Setelah melihat fakta fisik kebangkitan ini, Tomas langsung menyembah dan berkata kepada-Nya,"Ya Tuhanku dan Allahku!" (Yoh.20:27-29). Yesus menegaskan, "karena engkau telah melihat Aku, maka engkau percaya." Tidak seorang pun boleh disembah selain Allah, baik nabi, rasul maupun malaikat. Tetapi Yesus membiarkan Tomas menyembah. Yesus menerima penyembahan Tomas. Adegan itu akan sangat aneh jika Yesus bukan Tuhan. Tetapi jika Yesus bukan Tuhan, Ia seharusnya meminta Tomas bangkit sebelum ia berkata kepada-Nya,"Ya Tuhanku dan Allahku!" Dan faktanya Yesus tidak menolak, menyangkal, menarik kembali atau mengoreksi perkataan Tomas tersebut. Yesus menegur Tomas karena ketidakpercayaannya, bukan karena menyembah Dia.

\section{Yesus Menyejajarkan diri-Nya dengan Bapa}

Formulasi di dalam perintah baptisan, agar kita membaptis seseorang "Dalam nama Bapa dan Anak dan Roh Kudus" (Mat.28:19). Formula baptisan ini sangat jelas menunjukkan kesetaraan Yesus dengan Bapa. Seandainya Yesus bukan Allah, maka siapakah Dia? Siapakah “Anak"? F.F. Bruce dan W.J. Martin mengemukakan demikian:

No clearer expression of the fact of the Trinity could be desired than that given by the risen Christ in the baptismal formula in Matthew 28:19, with its inescapable implication of the coequality and hence co-eternity of the three persons of the Godhead. 'Go, therefore, and make disciples of all nations, baptizing them into the name of the Father and of the Son and of the Holy Spirit'. Notice that our Lord said 'name' not 'names'. There subsist three co-eternal persons, but the Divine essence or substance is one. ${ }^{14}$

Kata nama di dalam teks Yunani Matius 28: 19 tersebut adalah onoma dalam bentuk tunggal, bukan jamak (onomata). Secara tata bahasa, seharusnya kata nama di sini memakai bentuk jamak, sebab Bapa satu Pribadi, Anak juga satu Pribadi, dan Roh Kudus juga satu Pribadi. Inilah doktrin Tritunggal yang benar. Tetapi di dalam ayat ini satu nama tiga Pribadi yang kekal. Kata onoma menekankan pada satu "nama". Hal itu berarti Yesus memiliki esensi atau substansi Ilahi. Jadi, dalam rumusan baptisan yang diperintahkan oleh Yesus itu terlihat jelas bahwa kesetaraan dan kesatuan dari ketiga Pribadi itu termaksud di dalamnya. Bapa, Anak, dan Roh Kudus adalah sama dan sama-sama Allah. Dan juga di Yohanes 14:16 kesatuan ketiga-Nya kembali disebut: Anak meminta kepada Bapa yang mengutus Roh Kudus untuk tinggal di dalam orang percaya selamanya.

\section{4), 16}

${ }^{14}$ F.F. Bruce \& W.J. Martin, The Deity of Christ (Manchester: North of England Evangelical Trust, 


\section{Pengakuan Tidak Langsung}

Bukan saja Yesus secara langsung mengklaim sebagai Allah, tetapi Ia membuat banyak pernyataan yang secara tidak langsung tersirat keilahian-Nya. Yesus tidak hanya mengaku sebagai Allah tetapi juga memberikan banyak bukti meyakinkan bahwa Ia memang ilahi. Dalam banyak kesempatan Yesus mengakui keilahian-Nya secara tidak langsung. Bagaimana kemudian Yesus secara implisit mengklaim keilahian-Nya, dan apa yang dinyatakan oleh klaim-Nya?

\section{Yesus Menghakimi Umat Manusia}

Yesus mengklaim mengetahui pikiran-pikiran, sifat batiniah, kemunafikan manusia (Mat 9: 4; 12:25; 22:18). Karena itu Ia menubuatkan bahwa Ia akan menghakimi umat manusia pada hari terakhir (Mat.7: 22-23). Ia akan mengirim malaikat-malaikat-Nya untuk menyingkirkan penjahat dari dalam kerajaan-Nya (13:41) dan memberi upah kepada setiap orang sesuai dengan apa yang telah dia lakukan (Mat. 16:27). Pada hari penghakiman Ia akan memanggil bangsa-bangsa di hadapan tahta-Nya dan Ia akan memisahkan seorang dari seorang, sama seperti gembala memisahkan domba dari kambing, dan Ia akan menempatkan domba-domba dis ebelah kanan-Nya dan kambing-kambing di sebelah kiriNya. Kepada yang di sebelah kanan-Nya, Ia berkata: “...terimalah Kerajaan yang telah disediakan bagimu sejak dunia dijadikan” (ay.34). Sebaliknya, kepada yang di sebelah kiriNya, Ia berkata: "Enyahlah dari hadapan-Ku, hai kamu orang-orang terkutuk, enyahlah ke dalam api yang kekal yang telah disediakan untuk Iblis dan malaikat-malaikatnya" (ay.41).

Hukuman bagi orang fasik ini hendak menyatakan bahwa hakikat hukuman mereka bukan sekadar pemisahan dari Allah tetapi pemisahan dari Yesus. ${ }^{15}$ Yesus melakukan hak yang hanya bisa dilakukan oleh Allah semata. Seperti yang tertulis di dalam Mazmur 75:7, "Tetapi Allah adalah Hakim: direndahkan-Nya yang satu dan ditinggikan-Nya yang lain." Dengan demikian, berarti Yesus adalah Allah. Dia adalah Hakim yang adil. Yesus memiliki kekuatan untuk menghukum seperti Allah (Mat 25: 31-46). Karena itu, sekali lagi, Yesus melakukan apa yang dilakukan dalam perumpamaan-Nya sendiri, dan dengan demikian secara implisit mengklaim keilahian-Nya.

\section{Yesus Mengklaim Diri-Nya tidak Berdosa}

Apabila Yesus itu hanyalah manusia biasa, maka Ia dapat berbuat kesalahan. Yesus bersaksi akan diri-Nya dengan berkata, "Siapakah di antaramu yang membuktikan bahwa Aku berbuat dosa?" Yesus menantang mereka yang mendakwa-Nya untuk membuktikan bahwa Dia berdosa. Tidak ada satu ayat pun di Alkitab yang menuliskan bahwa Yesus pernah memohon pengampunan atas dosa-dosa-Nya karena memang Dia tidak berdosa. Yudas pun setelah mengkhianati Yesus menyadari dan sangat menyesal karena ia telah "menyerahkan darah orang yang tak bersalah" (Mat. 27:3-4). Sebagai tambahan, selain Injil-injil, para rasul bersaksi bahwa Yesus tidak berdosa, "Ia tidak berbuat dosa, dan tipu daya tidak ada dalam mulut-Nya" (1 Ptr. 2:22). Rasul Yohanes juga mengatakan, "Dan kamu tahu, bahwa Ia telah menyatakan diri-Nya, supaya Ia menghapus segala dosa, dan di

\footnotetext{
${ }^{15}$ Doraini, “The Deity Of Christ In The Synoptic Gospels" 0
} 
dalam Dia tidak ada dosa" (1 Yoh. 3:5). Paulus juga memberi kesaksian tentang ketidakberdosaan Yesus, "Dia yang tidak mengenal dosa telah dibuat-Nya menjadi dosa karena kita, supaya dalam Dia kita dibenarkan oleh Allah" (2 Kor. 5:21). Semua musuhNya yang berusaha mengajukan tuduhan agar dapat membuktikan kesalahan-Nya tidak berhasil (Mrk. 14:55-56). ${ }^{16}$

\section{Yesus dapat Mengampuni Dosa}

Dengan jelas Ia menyatakan diri-Nya dapat mengampuni dosa—seluruh dosa manusia (Luk.5:20). Tentu saja orang-orang Yahudi melancarkan protes terhadap klaim-Nya dengan mengatakan,"Siapa yang dapat mengampuni dosa-dosa, selain Allah sendiri?" (Luk.5:21). Yesus secara eksplisit dan terbuka mengampuni dosa pada dua kesempatan yang dicatat oleh Injil (Luk. 5: 17-26; 7: 36-50). Dia juga menentukan siapa yang mungkin dan siapa yang tidak diampuni (Luk. 18: 9-14). Pada yang pertama dari peristiwa-peristiwa ini Yesus menyembuhkan seorang lumpuh yang telah diturunkan melalui atap. Yesus mengajar dan menyembuhkan orang-orang di sebuah rumah di Galilea (Lihat Markus 2; Lukas 5). Orang-orang Farisi dan ahli-ahli Taurat turut hadir di rumah itu. Beberapa teman seorang lumpuh membawanya kepada Yesus untuk disembuhkan. Bertekad untuk membawanya kepada Yesus tetapi dihalangi oleh orang banyak, mereka naik ke atap rumah, lalu membongkar atap itu, dan menurunkan orang lumpuh itu dengan tempat tidurnya ke tangah-tengah orang banyak tepat di depan Yesus. Ketika Yesus melihat iman pria dan teman-temannya, berkatalah Yesus: "Hai saudara, dosamu sudah diampuni" (ay.20).

Pemikiran Yahudi berasumsi bahwa hanya pihak yang tersinggung yang dapat memaafkan dan melakukan pelanggaran. Lalu mengapa Yesus harus memaafkan pria yang tidak pernah Dia temui? Karena entah bagaimana orang lumpuh berdosa terhadap-Nya. Tetapi hanya Allah yang tersinggung oleh setiap dosa. Orang-orang Farisi memahami hal ini dan menyimpulkan: "Orang ini menghujat. Siapa yang dapat mengampuni dosa selain dari Allah saja?" (Mat 9: 3; Luk. 5:21). Yesus, mengetahui pikiran mereka, lalu Ia bertanya kepada mereka: "Mana yang lebih mudah: mengatakan, 'Dosamu sudah diampuni,' atau mengatakan: 'Bangunlah, dan berjalanlah?' Tetapi supaya kamu tahu, bahwa Anak Manusia memiliki kuasa di bumi untuk mengampuni dosa ... "Lalu Ia berkata kepada orang lumpuh itu," Bangunlah, angkatlah tempat tidurmu dan pulanglah ke rumahmu!'(ay. 24). Kemudian atas perkataan Yesus, pria itu bangun dan pulang ke rumah.

Klaim Yesus dapat mengampuni dosa itu tersirat keilahian-Nya. Yesus mengaku sebagai Allah. Seperti yang dikemukakan John Stott: that Jesus' claims to forgive sins... imply his deity). ${ }^{17}$ Menurut Doriani tindakan Yesus mengampuni dosa dan menyembuhkan orang lumpuh, sebenarnya Ia mendeklarasikan keilahian-Nya. Ia adalah Allah. Ia mengaku sebagai Allah: So Jesus says, in effect, "I have forgiven him, I do claim to be God..."18 Bagaimana Yesus dapat mengetahui dosa-dosa seseorang (Mrk.2:1-12), apalagi menawarkan pengampunan — seolah-olah Ia adalah Allah. Apakah Yesus berlaku som-

\footnotetext{
${ }^{16}$ Stevanus, Apologetika: Benarkah Yesus Itu Tuhan? 231-232

${ }^{17}$ Stott, Yesus Autentik (Jakarta: Logos, 1989), 29

${ }^{18}$ Doriani, "The Deity Of Christ In The Synoptic Gospels"
} 
bong? Yesus tidak berlaku sombong. Ia berkata benar. Inilah buktinya: "Supaya kamu tahu, bahwa Anak Manusia (Yesus) berkuasa mengampuni dosa ...”. Satu-satunya Pribadi yang memiliki hak untuk mengampuni dosa, yakni Allah sendiri. Jelas menurut hukum Yahudi, hanyalah Allahlah yang melakukannya, karena hanya Allahlah yang dapat mengampuni dosa. Karena perbuatan atau pengakuan Yesus ini, Dia dituduh telah menghujat Allah oleh ahli-ahli Taurat dan orang-orang Farisi. Yesus dihukum mati karena telah mengakui hak prerogatif Allah.

Kuasa Yesus untuk mengampuni orang atas dosanya merupakan contoh yang sangat menakjubkan bahwa Ia menggunakan hak yang hanya dimiliki oleh Allah. Hanya Allah yang memiliki otoritas untuk mengampuni dosa. Yesus punya otoritas untuk mengampuni dosa. Karena itu, Yesus adalah Allah. Dengan mengampuni dosa orang ini, Yesus melakukan tindakan ilahi. Dia melakukan apa yang hanya Allah memiliki kemampuan dan wewenang untuk melakukannya. Haregraaff berkata: In doing so, He claimed a prerogative reserved for God alone. ${ }^{19}$

Berkaitan dengan mukjizat menyembuhkan orang lumpuh, harus dibedakan dari mukjizat para rasul dan nabi di mana mereka tidak pernah melakukan dengan kekuatannya sendiri dan atas namanya sendiri. Sedangkan Yesus melakukannya atas otoritas-Nya sendiri dan nama-Nya sendiri. Ia berkata kepada orang lumpuh itu,"Bangunlah, angkatlah tempat tidurmu dan pulanglah ke rumahmu!" Yesus melakukan mukjizat atas otoritas-Nya sendiri. Yesus mengotorisasi diri-Nya sendiri karena memang Dia adalah Allah.

\section{Yesus Memberikan Hidup Kekal}

Klaim ini terkait paling erat dengan Injil Yohanes. Yesus berakata: "Aku adalah kebangkitan dan hidup. Siapa yang percaya kepada-Ku tidak akan mati" (Yoh.11:25, band 1 Yoh.5:11-12, "Barangsiapa memiliki Anak, ia memiliki hidup; barangsiapa tidak memiliki Anak, ia tidak memiliki hidup." Itu berarti di dalam Yesus ada hidup. Juga di dalam Injil Sinoptik sangat jelas Yesus memang menawarkan kehidupan kekal kepada pemuda yang kaya itu jika ia menjual hartanya dan mengikuti-Nya, maka ia beroleh hidup kekal (Mat.10: 17-21; Mat 19: 16-21; Luk.18: 18-22). ${ }^{20}$ Pernyataan Yesus bahwa Ia menawarkan kehidupan kekal, hal itu memiliki implikasi bahwa mereka yang percaya kepada Yesus tidak akan mati karena mereka telah memasuki kehidupan kekal. Pernyataan tersebut berakar pada pemahaman yang yang diungkapkan dalam Yohanes 10: 33-38 di mana Yesus berkata “...bahwa Bapa di dalam Aku dan Aku di dalam Bapa.” Itu sebabnya orang-orang Yahudi hendak melempari Yesus dengan batu, sebab Ia dianggap menghujat Allah atau menyamakan diri-Nya dengan Allah. ${ }^{21}$

\section{Nasib Kekal Manusia Bergantung pada Respons terhadap Yesus}

Kehidupan kekal diperoleh dengan cara datang kepada Yesus. Murid-murid-Nya harus mencintai-Nya lebih dari ayah atau ibu, putra atau putri, lebih dari hidup itu sendiri. Siapa pun yang tidak mau kehilangan nyawanya karena Kristus akan kehilangannya selamanya

\footnotetext{
${ }^{19}$ Hanegraaff, "Did Jesus Claim to be God?" p

${ }^{20}$ Doriani, 340-341

${ }^{21}$ Draper, "If those to whom the W/word of God came were called gods ...'
} 
(Mat.10: 37-39; 16: 24-26; Luk. 14: 26-27; Mark. 8: 34-38). Dengan ini Yesus memanggil orang untuk mencintai-Nya lebih dari siapa pun, untuk menaati perintah-perintah-Nya. Jika mereka mengakui kesetiaan kepada-Nya, mereka akan hidup selamanya. Jika tidak, mereka akan mengalami murka Allah yang kekal. Jika orang biasa mengatakan hal-hal seperti itu, dia akan tampak seperti penghujat bagi orang gila. Tetapi setidaknya untuk pembaca yang simpatik mereka bergema sebagai panggilan untuk mengambil keputusan: untuk mengikuti Yesus, untuk meniru-Nya, kehilangan semua untuknya, dan untuk mendapatkan semua. ${ }^{22}$

\section{Yesus Mengklaim Perkataan-Nya Bersifat Kekal}

Yesus menyatakan klaim bahwa perkataan-Nya kekal. Matius 5:18 Yesus berkata: "Karena Aku berkata kepadamu: Sesungguhnya selama belum lenyap langit dan bumi ini, satu iota atau satu titik pun tidak akan ditiadakan dari hukum Taurat, sebelum semuanya terjadi." Kita bisa bandingkan kesaksian nabi Yesaya tentang sifat kekal firman Allah: "Rumput menjadi kering, bunga menjadi layu, tetapi firman Allah kita tetap untuk selama-lamanya" (Yes.40:8). Yesus mengklaim bahwa kata-kata-Nya memiliki sifat kekal yang sama dengan milik Allah. Untuk kata-kata-Nya sendiri, Yesus mengajukan klaim yang serupa: "Langit dan bumi akan berlalu, tetapi perkataan-Ku tidak akan berlalu" (Mat. 24:35). Jika perkataan Yesus sama kekalnya dengan perkataan Allah berarti Dia adalah Allah. ia mengklaim bahwa kata-katanya memiliki keabadian yang sama dengan milik Allah (Yes. 40: 8).

Nash menyatakan:

Jika Yesus itu Allah, pengajaran-Nya bukanlah tebakan atau semata-mata hasil spekulasi manusia; perkataan Yesus adalah Firman Allah. Ini maksudnya bahwa memang benar-benar ada wahyu khusus ilahi di mana Allah menyatakan kebenaran-Nya kepada manusia. Selain itu, jika Yesus adalah Allah, kita memiliki lebih dari sekadar wahyu Allah dalam bahasa manusia. Allah telah menyatakan diri-Nya - pribadi-Nya, sifat-Nya, karaker-Nya_dalam cara hidup. Mengenal pengajaran Yesus berarti mengenal pengajaran Allah. ${ }^{23}$

\section{Yesus Mengidentifikasi Tindakan Terhadap Diri-Nya Sama dengan Tindakan Terhadap Allah}

Klaim ini juga terkuat di dalam Injil Yohanes, Yesus mengklaim bahwa mengenal diri-Nya berarti mengenal Allah (Yoh.8:19); melihat diri-Nya sama artinya melihat Allah (Yoh. 12:45; 14:7, 9); beriman kepada-Nya adalah sama artinya percaya kepada Allah (Yoh. 12:44; 14: 1); dan membenci-Nya adalah membenci Allah (Yoh. 15:23).

\section{Yesus Menyatakan Diri-Nya adalah Terang Dunia}

Terang Mesias yang akan datang ditunjuk dalam dua nubuat yang dikenal sebagai 'terang' (Yes. 9: 2, band Mat. 4:16; dan Yes. 49: 6, Luk. 2:32). Lima kali dalam pasal pertama Injil Yohanes ayat 4, 5, 7, 8, 9 deskripsi ini digunakan. Keunikannya ditekankan dalam ayat 9: 'Terang yang sesungguhnya'. Yesus sendiri berkata: 'Akulah terang dunia' (Yoh. 8:12). Dalam Perjanjian Lama “terang” itu menunjuk kepada Yahwe. Misalnya, Mazmur 27: 1:

\footnotetext{
${ }^{22} \mathrm{R}$ G Gruenler, New Approaches to Jesus A Phenomenological and Exegetical Study of Synoptic Christology (Grand Rapids Baker, 1982), 153-155

${ }^{23}$ Ronald H. Nash, Iman dan Akal Budi: Suatu Usaha Mencari Iman yang Rasional (Surabaya: Momentum, 2004), 413-414
} 
"TUHAN adalah terangku dan keselamatanku...", atau bahkan lebih khusus dalam Yesaya dalam konteks nubuat mesianis: “... TUHAN akan menjadi penerang abadi bagimu ..." (Yes. 60:19, 20). Sekali lagi, mengikuti nubuat tentang Mesias di dalam Yesaya 59:20 dan Yesaya 60: 1 secara jelas 'terang' itu menunjuk kepada Mesias, yakni Yesus disamakan dengan kemuliaan TUHAN (Yahwe).

Sangat instruktif untuk melihat bagaimana Yohanes dalam pengantar untuknya Surat pertama menggunakan julukan Allah yang sama dengan yang telah ia gunakan dalam ayat-ayat pembuka dari Injilnya tentang Anak yang berinkarnasi, yang ada di sana 'terang itu bercahaya di dalam kegelapan dan kegelapan itu tidak menguasainya (Yoh. 1:5). Selanjutnya dikatakan di dalam ayat 9, "terang yang sesungguhnya, yang menerangi setiap orang, sedang datang ke dalam dunia." Sedangkan dalam 1 Yohanes 1: 5, jelas dikatakan bahwa "...Allah adalah terang dan di dalam Dia sama sekali tidak ada kegelapan". Yesus mengambil bagi diri-Nya gelar umum untuk Yahwe dalam Perjanjian Lama, di mana TUHAN (Yahwe) adalah terang dunia yang abadi. Hanya Allah yang menjadi terang dunia. Hanya Allah yang bisa memberikan cahaya kehidupan. Jadi, dengan kata lain, Yesus sedang mengklaim diri-Nya adalah Allah, terang dunia.

\section{Yesus Mengambil Gelar TUHAN (Yahwe) bagi Diri-Nya}

Sebagai contoh adalah gelar Gembala. Mazmur 23: 1 berkata: "TUHAN adalah gembalaku ...", dan di dalam Yehezkiel 34:15 dikatakan: "Aku sendiri akan menggembalakan domba-domba-Ku...demikianlah firman Tuhan ALLAH.” Penulis Injil Yohanes menunjukkan bahwa Yesus menggunakan gelar diri Allah ini dengan mengatakan: "Akulah gembala yang baik ..." (Yoh.10:11, 14). Gembala yang baik menyerahkan nyawanya untuk domba-domba-Nya (Yoh.10:15). Untuk meyakinkan lagi, bisa dibandingkan dengan pernyataan rasul Petrus yang memanggil Yesus sebagai 'Gembala dan Penjaga jiwamu' (1 Ptr. 2:25), dan di dalam 1 Petrus 5:4, Yesus disebut "Gembala Agung”. Juga penulis surat Ibrani berbicara tentang Yesus sebagai Gembala Agung, ”...Gembala Agung segala domba, yaitu Yesus, Tuhan kita" (Ibr.13:20). Tidak dapat disangkal lagi, bahwa Yesus adalah Allah. Dia adalah Gembala Agung.

Jelaslah bahwa nubuat itu menunjuk kepada Yesus. Itu berarti Yesus adalah Tuhan (Yahweh) yang datang ke dunia dengan menjelma menjadi manusia di dalam Yesus. Bahkan dalam perumpamaan-Nya, Yesus menyatakan bahwa Ia mempunyai fungsi yang hanya diperuntukkan bagi Yahwe di Perjanjian Lama, seperti menjadi Gembala (Luk.15; Yoh.10:11-16). Di dalam Yesaya 40:10-11 dikatakan: "Lihat, itu Tuhan ALLAH, Ia datang dengan kekuatan dan dengan tangan-Nya Ia berkuasa. Lihat, mereka yang menjadi upah jerih payah-Nya ada bersama-sama Dia, dan mereka yang diperoleh-Nya berjalan di hadapan-Nya. Seperti seorang gembala ia menggembalakan kawanan ternak-Nya dan menghimpunkannya dengan tangan-Nya; anak-anak domba dipangku-Nya, induk-induk domba dituntun-Nya dengan hati-hati." Tentang Yesaya 40:10-11, Robert R. Selvendran menyimpulkan dengan tepat bahwa nubuat itu menunjuk kepada Yesus dan telah digenapi 
di dalam diri Yesus. Dengan kata lain, ia hendak mengatakan bahwa Yesus adalah sama dengan Tuhan (Yahweh). Melihat Yesus berarti melihat Tuhan (Yahweh). ${ }^{24}$

\section{Yesus Disebut Immanuel dan Juruselamat}

Dalam Matius 1:23 sebutan Imanuel jelas-jelas ditujukan kepada Yesus:"Sesungguhnya, anak dara itu akan mengandung dan melahirkan seorang anak laki-laki, dan mereka akan menamakan Dia Imanuel" -- yang berarti: Allah menyertai kita." Nuban Timo mengatakan Sang Anak adalah Tuhan yang berinkarnasi-Ia adalah Imanuel, Tuhan di antara kita. ${ }^{25}$ Menarik suatu kesimpulan dari fakta-fakta dan menyadari bahwa Yesus itu adalah Imanuel, karena itu Yesus tentu juga Allah. John Stott menegaskan bahwa transfer julukan-Allah dan teks-Allah dari Yahweh kepada Yesus mengindikasikan Yesus sebagai Allah, yang bisa menyelamatkan (Juruselamat) dan yang patut disembah. Menyembah Yesus, jika Dia bukan Allah, adalah pemujaaan terhadap berhala; tidak menyembah Dia, jika Dia Allah, adalah murtad. ${ }^{26}$ Pendapat yang sama dikemukakan Selvendran sebagai berikut:

What reasonable conclusions can one draw from these testimonies of the Scriptures? It is clearly asserted by Yahweh Himself, the Eternal God who created the world, that He is the Saviour; and further, that there is no Saviour besides Him. Yet in the same Scriptures it is asserted positively, over and over again, that Jesus Christ is the Saviour (Luke 2:11; Acts 5:31; 13:23), and that He it is who shall save His people from their sins (Matt. 1:21; Acts 4:12). Now how can these testimonies be reconciled, unless Jesus Christ is also Yahweh? Yahweh says of Himself, 'There is no Saviour besides Me' - and of Jesus Christ it is said, He is the 'Saviour of the world' (John 4:42). Therefore, Jesus Christ must be Yahweh God or it is plain there must be a Saviour besides Yahweh, which is contrary to His repeated and most positive declaration. ${ }^{27}$

Apa kesimpulan logis yang bisa ditarik seseorang dari kesaksian Alkitab ini? Jelas dinyatakan oleh Alkitab Yahweh adalah Juruselamat, dan Yesus disebut Juru selamat berarti Dia adalah Allah yang kekal yang menciptakan dunia, bahwa Dia adalah Juru selamat.

\section{Yesus adalah Kekal}

Yohanes berkata, "Pada mulanya adalah Firman; Firman itu bersama-sama dengan Allah dan Firman itu adalah Allah" (Yoh 1:1). Menjelaskan kata "pada mulanya..." di dalam Yohanes 1:1-3, menunjuk kepada permulaan dalam kekekalan, bukan permulaan dari waktu, bukan permulaan penciptaan. Mengapa demikian? Karena karya penciptaan baru disebutkan di dalam ayat kedua. Yesus sudah ada sejak kekekalan bersama Bapa, dan pada waktu berinkarnasi (dilahirkan) adalah sebagaimana Firman keluar. Pada waktu Firman itu "keluar", kita mengetahui ada yang menjadi "Sumber" dan "Yang keluar" dari Sumber itu. Firman keluar dari Tuhan; sebelum keluar Firman itu bersama-sama dengan Tuhan di dalam kekekalan, dan Firman itu juga adalah Tuhan. Selanjutnya di ayat 2, dijelaskan

\footnotetext{
${ }^{24}$ Robert R. Selvendran, The unique Divinity of Jesus Christ established from His naming as Saviour (Great Britain: Prontaprint Norwich, 2005), 8

${ }^{25}$ Ebenhaizer I. Nuban Timo, Allah Menahan Diri, Tetapi Pantang Berdiam Diri (Jakarta: BPK Gunung Mulia, 2015), 98

${ }^{26}$ Stott, Yesus Autentik, 36

${ }^{27}$ Selvendran, The unique Divinity of Jesus Christ established from His naming as Saviour, 10
} 
dengan gamblang bahwa Firman itu adalah Yesus, sebab itu Yesus bersifat Ilahi. Dia adalah Allah.

Di sini memang kita melihat dua Pribadi, tetapi bukan dua Tuhan. Dalam ayat 3, juga ditegaskan kembali bahwa Firman yang keluar itu adalah yang menciptakan dunia dan segala sesuatu,"Segalanya dijadikan melalui Dia, dan dari segala yang ada, tak satu pun dijadikan tanpa Dia." Kita bandingkan dengan Kolose 1:16, "Sebab melalui Dialah Tuhan menciptakan segala sesuatu di surga dan di atas bumi, segala sesuatu yang kelihatan dan yang tidak kelihatan, termasuk juga segala roh yang berkuasa dan yang memerintah. Seluruh alam ini diciptakan melalui Kristus dan untuk Kristus" (Kol 1:16; BIS). Siapakah yang dapat menciptakan kecuali Allah sendiri? Hanya Allahlah yang dapat menciptakan! Jadi, kalau dikatakan Firman itu (Yesus) menciptakan segala sesuatu, berarti Yesus adalah Pencipta, dan bahwa Yesus ialah Allah. Kalau Yesus diciptakan oleh Allah, bagaimana kita menjelaskan kalimat "tanpa Dia tidak ada suatu pun yang telah dijadikan?" Yohanes 1:3 (band. Kol. 1:16).

Selanjutnya pada ayat 14, dikatakan: "Firman itu telah menjadi manusia, dan diam di antara kita..." Kata "Firman" di sini adalah logos. Menurut D. Carson, ayat ini jelas mengimplikasikan adanya pra-eksistensi dan keilahian Yesus, di mana Yesus bersama dengan Bapa sebagai Pencipta dunia. ${ }^{28}$ Karena Logos (Firman) itu turun ke dunia menjadi manusia, maka Ia (Logos) itu pun diyakini pula telah mengenakan juga sifat kemanusiawian-Nya. Logos itu memiliki sifat ilahi dan sekaligus manusiawi. ${ }^{29}$ Karena Ia turun ke dunia, maka Ia (Yesus) pun diyakini pula telah mengenakan juga sifat kemanusiawiannya.

Tentang hubungan antara Bapa dan Anak dijelaskan Soedarmo sebagai berikut:

Sebutan ini menunjukkan kepada hubungan, yaitu Tuhan Bapa adalah Bapa, Tuhan Anak adalah Anak yang tunggal, jadi ada hubungan antara yang melahirkan dan yang dilahirkan. Akan tetapi hubungan ini tidak dapat kita pikirkan lebih lanjut sebab 'lahir' ini tidak dapat disamakan dengan 'lahir' dalam hidup manusia, oleh karena kedua pribadi, baik Bapa maupun Anak, adalah kekal. ${ }^{30}$

Jadi, istilah Anak Allah tidak boleh dipahami dengan konsep manusia yang terbatas. Kalau dikataan Yesus adalah Anak Allah itu benar; Yesus adalah Allah, itu juga benar, sebab Anak Allah adalah Allah. Paul Enns menambahkan istilah dilahirkan berdasarkan Matius 1:20, dinyatakan dengan jelas bahwa Yesus dilahirkan dalam kemanusian-Nya bukan dalam keilahian-Nya. Yesus adalah Allah dari sejak kekekalan seperti yang dituliskan oleh Nabi Mika (Mikha.5:2), tetapi di Bethelem Ia mengambil natur tambahan, yaitu natur manusia. Roh Kudus berperan dalam kandungan Maria untuk menjamin ketidakberdosaan kemanusiaan Yesus. Dengan referensi pada kemanusiaan Yesus, maka istilah dilahirkan itu digunakan; kata itu tidak akan pernah digunakan dengan referensi pada keilahian-Nya. ${ }^{31}$

${ }^{28}$ D.A. Carson dkk,Tafsiran Alkitab Abad Ke-21: Jilid 3 Injil Matius Wahyu (Jakarta: Yayasan Komunikasi Bina Kasih, 2017), 201

${ }^{29}$ Bambang Subandrijo, Yesus Sang titik Temu Dan Titik Tengkar: Sebuah Studi Tentang Pandangan Kristen dan Muslim Di Indonesia Mengenai Yesus (Jakarta: Unit Publikasi dan Informasi STT Jakarta dan BPK Gunung Mulia, 2016), 26

${ }^{30}$ Soedarmo, Ikhtisar Dogmatika (Jakarta: BPK Gunung Mulia, 1996), 124

${ }^{31}$ Paul Enns, Buku Pegangan Teologi (Malang: SAAT, 2012), 248 
Bart Larson mengatakan hanya Allah sajalah yang dinyatakan di Alkitab bersifat kekal. ${ }^{32}$ Jika sifat kekal ini dikenakan kepada Yesus berarti Ia adalah Allah.

\section{Kesimpulan}

Berdasarkan penyelidikan di dalam teks-teks keempat Injil, diperoleh kesimpulan bahwa klaim Yesus sebagai Allah adalah benar sebagaimana yang dinyatakan di dalam Injil-Injil tersebut. Ia menegaskan keilahian-Nya dengan menjalankan fungsi-fungsi, dengan asumsi hak prerogatif, atau menerima penghormatan yang benar-benar hanya milik Allah saja. Pertanyaan tentang siapakah Yesus sebenarnya menurut Injil-injil akhirnya terjawab bahwa Ia adalah Allah. Dia adalah manusia sejati dan sekaligus Allah sejati. Dengan demikian, tidak ada alasan untuk menolak keilahian Yesus.

\section{Referensi}

Carson, D.A. dkk. Tafsiran Alkitab Abad Ke-21: Jilid 3 Injil Matius Wahyu. Jakarta: Yayasan Komunikasi Bina Kasih, 2017

Doriani, Daniel. “The Deity Of Christ In The Synoptic Gospels” Journal Of The Evangelical Theological Society, Vol.37, No.3 September 1994

Draper, Jonathan A. "“If those to whom the W/word of God came were called gods ...'Logos, wisdom and prophecy, and John 10:22-30" HTS Teologiese Studies/Theological Studies, Vol. 71, Number 1, July 2015

Gunawan, Suliana "Rahasia Jati Diri Yesus Dalam Injil Markus: Suatu Tinjauan Terhadap Tesis William Wrede: VERITAS: Jurnal Teologi dan Pelayanan. Vo. 2, No 1 April 2001

Gruenler, R G. New Approaches to Jesus A Phenomenological and Exegetical Study of Synoptic Christology. Grand Rapids Baker, 1982

Hanegraaff, Hank . "Did Jesus Claim to be God?" Christian Research Journal, volume 28, number 4, 2005

McDowell, Josh. Apologetika Volume 1. Malang: Gandum Mas, 2002

McDowell, Josh dan Bart Larson, Adakah yang Mustahil bagi Allah? Allah menjadi Manusia. Bandung: Literatur Baptis, 2000

Nash, H. Iman dan Akal Budi: Suatu Usaha Mencari Iman yang Rasional. Surabaya: Momentum, 2004

Selvendran, Robert. R. The unique Divinity of Jesus Christ established from His naming as Saviour. Great Britain : Prontaprint Norwich, 2005

Soedarmo, Ikhtisar Dogmatika. Jakarta: BPK Gunung Mulia, 1996.

Stott, John. Basic Christianity. Downers Grove InterVarsity, t,th

Stott, John. Yesus Autentik. Jakarta: Logos, 1989

Stevanus, Kalis. Apologetika: Benarkah Yesus Itu Tuhan? Yogyakarta: Andi, 2016

Subandrijo, Bambang. Yesus Sang titik Temu Dan Titik Tengkar: Sebuah Studi Tentang Pandangan Kristen dan Muslim Di Indonesia Mengenai Yesus. Jakarta: Unit Publikasi dan Informasi STT Jakarta dan BPK Gunung Mulia, 2016

Timo, Ebenhaizer I. Nuban, Allah Menahan Diri, Tetapi Pantang Berdiam Diri. Jakarta: BPK Gunung Mulia, 2015

\footnotetext{
${ }^{32}$ Josh McDowell dan Bart Larson, Adakah yang Mustahil bagi Allah? Allah menjadi Manusia (Bandung: Literatur Baptis, 2000), 64.
} 